\title{
Analysis Malware Flawed Ammyy RAT Dengan Metode Reverse Engineering
}

\author{
Tesa Pajar Setia ${ }^{1 *)}$, Nur Widiyasono ${ }^{2}$, Aldy Putra Aldya ${ }^{3}$ \\ ${ }^{1}$ Jurusan Informatika, Fakultas Teknik, Universitas Siliwangi, Tasikmalaya \\ ${ }^{1} \mathrm{Jln}$. Siliwangi no 24, Kota Tasikmalaya, 46115, Indonesia \\ email: ${ }^{1}$ tesa.paja14@ student.unsil.ac.id, ${ }^{2}$ nur.widiyasono@ unsil.ac.id, ${ }^{3}$ aldy@ unsil.ac.id
}

Received: 30 Juli 2018; Revised: 1 Oktober 2018; Accepted: 20 Oktober 2018

Copyright $\odot 2018$, Politeknik Harapan Bersama, Tegal

\begin{abstract}
Malware is currently growing rapidly, diverse and complex. But, human resources that can carry out malware analysis is limited, because special expertise is needed. Reverse engineering is one of many solution that can carry out malware analysis, because reverse engineering techniques can reveal malware code. On March 5, 2018, found spam email containing files, the file contained malware flawed ammyy. This flawed ammyy is a software that comes from Ammyy Admin version 3 and then misused by hackers TA505. This study aims to identify the malware, especially the Flawed Ammyy RAT malware. This research uses descriptive methodology, then to do malware analysis used dynamic analysis and reverse engineering methods. The results of the study show that the Flawed Ammyy RAT malware works by hiding in the Ammyy Admin application then connecting to the attacker with ip address 103.208.86.69. netname ip address 103.208.86.69 is zappie host. There are 50 registry changes that are carried out by malware on infected systems. After the attacker has been connected with the victim, the attacker can easily do the remote control without the victim's knowledge.
\end{abstract}

Abstrak - Malware saat ini berkembang dengan pesat, beragam dan komplek. Namun kurangnya sumber daya manusia yang dapat melakukan analisis malware karena diperlukan keahlian khusus. Reverse engineering merupakan salah satu solusi untuk melakukan analisis malware karena menggunakan teknik reverse engineering kode pada malware dapat diketahui. 5 Maret 2018 ditemukan spam email yang berisi file, file tersebut terdapat malware flawed ammyy. Flawed ammyy ini merupakan software yang berasal dari Ammyy Admin versi 3 kemudian disalah gunakan oleh hacker TA505. Penelitian ini bertujuan untuk melakukan proses identikasi malware kususnya malware Flawed Ammyy RAT. Penelitian ini menggunakan metodologi deskriptif, kemudian untuk melakukan analisis malware digunakan metode analisis dinamis dan reverse engineering. Hasil dari penelitian menunjukan bahwa malware Flawed Ammyy RAT bekerja dengan bersembunyi pada aplikasi Ammyy Admin kemudian melakukan koneksi dengan attacker dengan ip address 103.208.86.69. netname ip address 103.208.86.69 adalah zappie host. Perubahan 50 registry yang dilakukan malware pada system yang terinfeksi. Setelah attacker terkonesi dengan korban maka attacker dengan mudah melakukan remote control tanpa sepengetahuan korban.

Kata Kunci - Ammyy, Flawed, Engineering, Malware, Reverse

*) Corresponding author: (Tesa Pajar Setia)

Email: tesapajarsetia27@gmail.com

\section{PENDAHULUAN}

Internet telah menjadi bagian penting dari kehidupan sehari-hari bagi orang-orang. Internet dapat membantu seseorang memanfaatkan banyak layanan hanya dengan bantuan beberapa klik [1]. Tingginya penggunaan internet menciptakan kejahatan tak hanya terjadi dalam dunia nyata, tetapi merambah ke dunia maya yang sering disebut sebagai cybercrime [2]. Kejahatan di dunia cyber saat ini beragam. Teknik yang digunakan oleh penyerang semakin beragam dan kompleks. Berbagai serangan tersebut diantranya melibatkan malicious software atau yang biasa disebut malware yang merupakan suatu program jahat [3]. Beragam tujuan yang dimiliki para pelaku ini beberapa diantaranya adalah untuk mencari kesenangan dan mencari keuntungan [4].

Malware diciptakan dengan maksud tertentu yaitu melakukan aktifitas berbahaya yang berdampak sangat merugikan bagi para korbannya, antara lain seperti penyadapan serta pencurian informasi pribadi [5]. Malware dapat berisi kode berbahaya seperti Virus, Worm, Trojan Horse, juga bisa membuat Back Door yang dapat melakukan pencurian informasi pribadi atau mengambil kendali sistem seseorang [6]. Seringkali malware masuk ke sistem melalui file yang diunduh. Setelah malware memasuki sistem, malware melakukan aktivitas dan merusak seluruh sistem [7].

Kemampuan untuk melakukan analisa malware bagi seorang investigator menjadi tuntutan dalam setiap melakukan investigasi. Meningkatnya sejumlah malware serta evolusi dan mampu beradaptasinya terhadap perangkat analisis yang selama ini digunakan [8]. Analisa malware dengan menggunakan Reverse engineering merupakan salah satu solusi yang bisa digunakan saat ini. Reverse engineering dalam analisis malware berguna untuk ekstraksi data yang memuat informasi yang ada didalam malware [9].

Para analis Proofpoint telah menemukan Trojan akses jarak jauh yang sebelumnya tidak terdokumentasi yang disebut Flawed Ammyy RAT [10]. Malware Flawed ammyy dibangun diatas kode Ammyy adminversi versi 3 yang disalah gunakan. Ammyy admin merupakan perangkat lunak desktop jarak jauh yang digunakan diantara jutaan konsumen dan bisnis untuk menangani remote control dan diagnosis pada platfom Windows, ini bukan pertama kalinya Ammyy admindisalahgunakan, serangan Juli 2016 juga menggunakannya untuk menyembunyikan malware [11]. 
Penyerang yang mendistribusikan Flawed ammyy remote control trojan melalui kelompok peretas TA505 yang terkenal karena mendistribusikan kampanye spam besar seperti Trojan Dridex perbankan, Locky ransomware, dan Jaff ransomware. [12]

\section{PENELITIAN YANG TERKAIT}

Penelitian yang telah dilakukan sebagai dasar mengenai penelitian ini diantaranya [13] menjelaskan penggabungan dari dua metode analisis malware yaitu analisis statis dan analisis dinamis mampu memberikan gambaran yang lebih lengkap tentang karakteristik dari malware TT.exe. Malware TT.exe adalah malware tipe trojan, dibuat pada hari Rabu 30 Juli 2014, menargetkan windows 7 dan windows 8 .

Peneltian [1] melakukan analisis statis dan analisis dinamis pada malware DrakComet. Hasil dari penelitian ini adalah menguraikan metodologi yang efektif dan efisien yang dapat diterapkan untuk meningkatkan kinerja deteksi dan penghapusan malware yang dikumpulkan. Analisis dinamis cara terbaik untuk melakkan analisis sample malware.

Penelitian [14] menjelaskan hasil komparasi terhadap metode analisis malware statis. Peneliti melakukan ekstraksi 11 vektor kelompok kecil untuk 600 malware, dan berhasil mengklasifikasikan lebih dari setengah kode ke dalam kelompok yang sesuai menggunakan vektor. Pemeriksaan yang cermat pada kode biner juga menegaskan bahwa vektor bit telah mengklasifikasikannya dengan cara yang benar. Hasil eksperimen menunjukkan bahwa bit vektor dapat digunakan secara efektif untuk melakukan analisis malware statis, dan bahwa vektor bit grup dapat membantu mengklasifikasikan malwares ke dalam kelompok yang sesuai.

Penelitian [9] melakukan proses reverse engineering pada malware Biscuit. Hal mendasar dari cara kerja malware tersebut adalah adanya auto request untuk koneksi ke ip tertentu yaitu ip pada alamat: 114.101.115.115. Selanjutnya proses reverse engineering melalui penulusuran perintah: bdkzt, ckzjqk, download, exe, exit dan lists telah dapat memetakan bagaimana cara kerja dari malware Biscuit.

Peneliti [15] melakukan reverse engineering untuk membedah kode ransomware kemudian analisis lebih lanjut. Hasil menunjukkan bahwa meskipun penggunaan enkripsi tangguh, seperti ransomware lain menggunakan serangan yang sama struktur dan primitif kriptografi. Analisis menuntun pada kesimpulan bahwa strain ransomware ini tidak serumit dilaporkan sebelumnya. Analisis praktis terperinci ini mencoba meningkatkan kesadaran kepada komunitas bisnis tentang realitas dan Pentingnya keamanan TI sementara mengisyaratkan pencegahan, pemulihan dan keterbatasannya.

Peneliti [16] melakukan reverse engineering pada malware botnet. Tujuan utama dari penelitian ini adalah untuk menentukan pendekatan yang paling memadai untuk menciptakan kembali insiden botnet. Gangguan jaringan pada proses ini, aktivitas online ilegal dan pencurian data organisasi dapat dicegah dan bahkan bot sistem Intrusion Prevention spesifik dapat dikembangkan. Ini juga menjamin aliran data yang dikonfirmasi dalam ruang digital oleh komunikasi e-governance yang diasuransikan untuk setiap negara dari terorisme cyber.
Hasil dari studi literatur yang telah dilakukan, jika dibandingkan dengan penelitian kali ini, analisis terhadap sample malware Flawed ammyy RAT menggunakan analisis dinamis dengan tambahan membuat virtual network pada virtual mesin agar system terlihat melakukan koneksi pada suatu jaringan. Reverse engineering yang dilakukan sebelumnya menggunakan teknik debugger dan assembler sedangkan penelitian kali ini menggunakan disassembler.

\section{METODE PENELITIAN}

Metodologi yang digunakan pada penelitian ini menggunakan metodologi deskriptif dengan alur seperti pada Gbr 1 sebagai berikut:

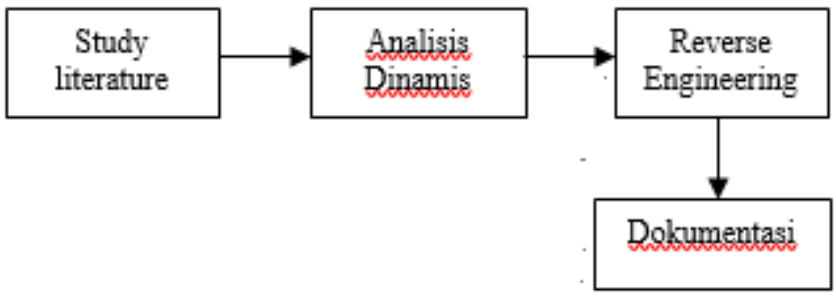

Gbr. 1 Alur penelitian

\section{A. Studi Literature}

Study literature uraian tentang teori, temuan, dan bahan penelitian lainnya yang diperoleh dari bahan acuan untuk dijadikan landasan kegiatan penelitian untuk menyusun kerangka pemikiran yang jelas dari perumusan masalah yang ingin diteliti. Bahan acuan yang digunakan adalah jurnaljurnal dan buku mengenai analisis malware dan reverse engineering malware.

\section{B. Analisis Dinamis}

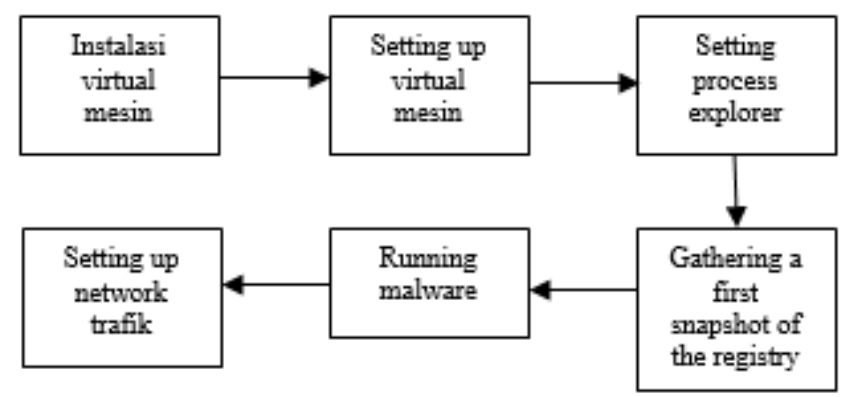

Gbr. 2 Alur metode analisis dinamis

\section{1) Instalasi virtual mesin}

Menentukan ruang lingkup, penelitian ini mengkhususkan pada ruang penelitian yang akan dilakukan pada lingkungan aman dimana menggunakan lingkungan virtual untuk pengujian sample virus. Lingkungan mesin virtual atau yang dikenal dengan virtual mechine (VM). Spesifikasi yang akan di gunakan sebagai penelitian adalah sperti pada Tabel I. 
TABEL I

SPESIFIKASI KOMPUTER

\begin{tabular}{|l|l|l|}
\hline No & \multicolumn{1}{|c|}{ Uraian } & \multicolumn{1}{c|}{ Spesifikasi } \\
\hline 1 & Sistem operasi & $\begin{array}{l}\text { Windows 7 Ultimate 32-bit (6.1, } \\
\text { Build 7601) Service Pack 1 }\end{array}$ \\
\hline 2 & Prosesor & $\begin{array}{l}\text { Intel(R) Core(TM) i3-2350M } \\
\text { CPU @ 2.30GHz (4 CPUs), } \\
\end{array}$ \\
& & 4.3GHz \\
\hline 3 & Memory & RAM \\
\hline 4 & Hardisk Capacity & 500 \\
\hline
\end{tabular}

TABEL II

SPESIFIKASI VIRTUAL

\begin{tabular}{|l|l|l|}
\hline No. & \multicolumn{1}{|c|}{ Uraian } & \multicolumn{1}{c|}{ Spesifikasi } \\
\hline 1 & Aplikasi VM & Virtual Box \\
\hline 2 & Sistem operasi & Windows7 \\
\hline 3 & Memori & 30MB / 1GB RAM \\
\hline 4 & Processor & Single core \\
\hline
\end{tabular}

Tabel I dan Tabel II merupakan spesifikasi lab yang digunakan untuk membuat vitual mesin yang digunakan untuk melakukan analisis malware.

\section{2) Setting up virtual network}

Setting up virtual network menggunkana tools ApateDNS. ApateDNS untuk melihat apakah permintaan DNS dilakukan. ApateDNS memalsukan respons DNS ke alamat IP yang ditentukan pengguna pada komputer lokal, ini menanggapi permintaan $D N S$ dengan respons $D N S$ diatur ke alamat $I P$ yang ditentukan. ApateDNS dapat ditampilkan hasil heksadesimal dan ASCII dari semua permintaan yang diterimanya.

\section{3) Starting process explorer}

Monitoring process menggunakan process Hacker 2.39, Process Hacker 2.39 menunjukan informasi tentang penanganan dan proses $D L L$ yang telah berjalan. Pembahasan lengkap untuk analisis menggunakan Process Explorer 2.39 akan dilakukan pada langkah berikutnya.

\section{4) Gathering first snapshot of the registry}

Analisis berikutnya adalah memonitor perubahan pada registri. Hasil dari Regshot 1.9.0 ini bisa dipilih, berupa file teks atau HTML, yang menunjukkan berapa jumlah perubahan registri dan apa serta dimana saja perubahan tersebut. Pembahasan lengkap untuk analisis menggunakan Regshot akan dilakukan pada langkah selanjutnya.

\section{5) Running malware}

Dalam tahap ini dilakukan pengujian dengan menjalankan sampel file malware (Flawed Ammy RAT) pada virtual lab, sehingga dapat menghasilkan informasi mengenai perilaku apa saja yang dilakukan oleh malware terhadap sistem ketika file tersebut dijalankan. Malware Flawed Ammy rat ini file exe maka menjalankannya dengan double clik malware tersebut.

6) Setting up network traffic

Monitoring lalu lintas jaringan, WireShark karena memiliki tampilan antarmuka (GUI) dan fitur filtrasi sehingga sangat mudah dalam penggunaannya. WireShark sudah cukup untuk meneliti paket yang berada pada jaringan yang mungkin dikirim oleh malware. Analisis menggunakan WireShark untuk pembahasan lengkap akan dilakukan pada langkah selanjutnya.

\section{Reverse engineering}

Proses disassembly digunakan dalam teknik Reverse engineering untuk menerjemahkan dari bahasa mesin ke bahasa yang mudah dimengerti manusia, yaitu bahasa assembly [9].

\section{Dokumentasi}

Dokumentasi menyimpan hasil keluaran data dari pengolahan proses scan dari sample malware dari berbagai software analisis, untuk kemudian diterapkan pada jurnal penelitian.

\section{HASIL DAN PEMBAHASAN}

A. Analisis dinamis

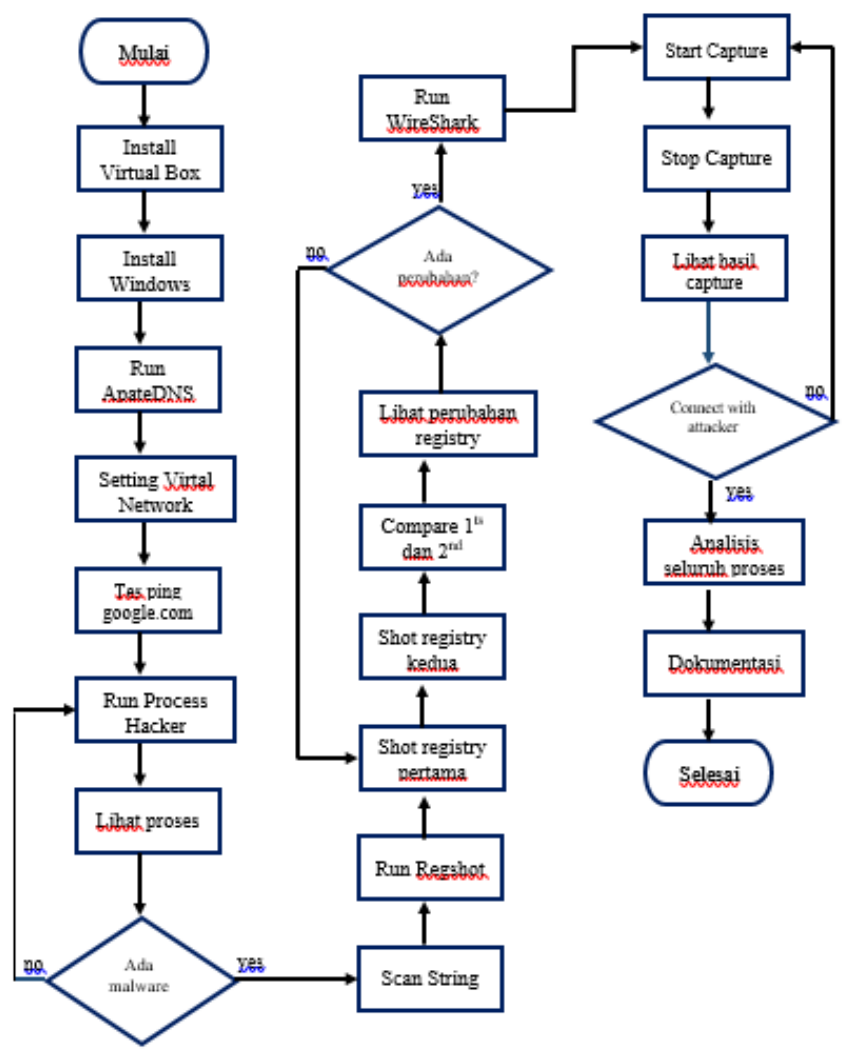

Gbr. 3 flowchart analisis dinamis

Pada Gbr. 3 menunjukan bagaimana cara melakukan analisis dinamis khususnya analisis malware flawed ammyy RAT. Sesuai Gbr.3 penjelasan lebih lengkap sebagai berikut:

\section{1) Instalasi Virtual Mesin}

Penggunaan sistem pada virtualbox yaitu operating system yang digunakan menggunakan windows 7 , kemudian untuk memory yang di berikan yaitu sebesar 512MB dan 1 buah processor dengan kapasitas penyimpanan yaitu 30GB, untuk jaringan yang digunakan tidak dianjurkan untuk menggunakan network Bridge conection ataupun Host-only 
conection, dikarenakan pada bridge connection jaringan akan secara langsung terhubung dengan jaringan komputer fisik. Network yang digunakan pada praktek penelitian ini yaitu NAT pada jaringan merupakan langkah aman untuk melakukan uji coba karena pada prakteknya data tidak akan langsung dikirimkan pada komputer fisik data yang dikirim harus melalui perangkat NAT dan Firewall terlebih dahulu.

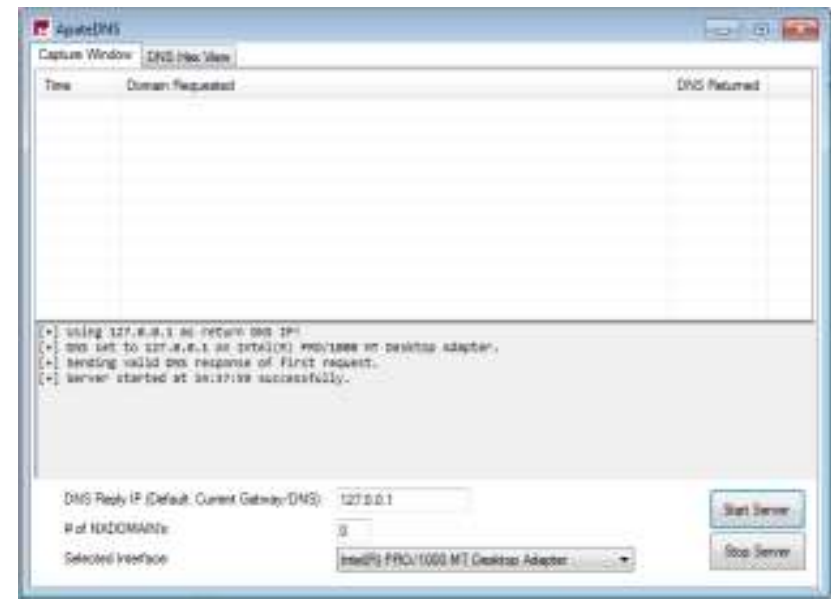

Gbr. 4 ApateDNS

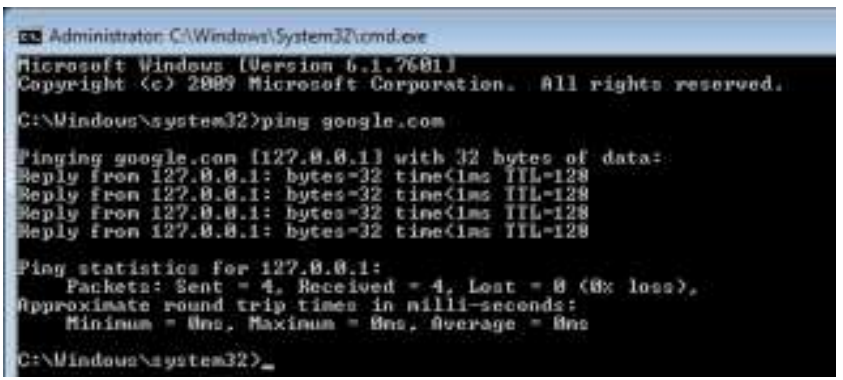

Gbr .5 Ping google pada cmd virtual mesin

\section{2) Setting up virtual network}

Tools yang digunakan untuk proses setting up virtual network menggunakan ApateDNS. ApateDNS ini telah diinstal pada virtual mesin selanjutnya DNS reply ip di ubah menjadi ip address localhost yakni 127.0.0.1 kemudian tekan tombol start server seperti pada Gbr 4. Mengetahui apakah setting up virtual mesin ini berhasil atau tidak, buka CMD pada lab virtual mesin tersebut kemudian ping ke alamat google.com seperti pada Gbr 5. Hasil dari Gbr 5 menunjukan bahwa virtual network telah berhasil dilakukan setting up, ini terbukti dengan ketika dilakukan ping google pada cmd ip address yang dituju menuju ip addres yang telah dilakukan setting up pada ApateDNS.

\section{3) Starting process explorer}

Tahap staring process explore ini menggunakan tools process hacker versi 2.39. Process Hacker merupakan aplikasi untuk menampilkan proses apa saja yang dijalankan, untuk kelebihan aplikasi ini portable yang tidak membutuhkan proses instalasi. Aplikasi ini memiliki fitur yang hampir sama dengan process explorer dan memiliki semua fungsionalitas yang diberikan Process Explorer, namun memiliki banyak kelebihan, salah satu contohnya mempunyai fitur scan string yang lebih, mengijinkan melihat thread apa yang berjalan, dan informasi detai lainnya.

Tahap selanjutnya malware Flawed Ammyy RAT runnig. Setalah malware tersebut dilakukan runnig lihat proces pada process hacker seperti pada Gbr 6 .

Merujuk pada Gbr 6 malware berjalan dengan no pid 2300 dengan menggunakan 0.65 proces pada cpu virtual dengan besar file 4.13MB. Informasi lebih detail dapat menggunakan fitur lain yang ada pada process hacker contohnya ialah scan string, yang akan ditunjukan pada Gbr 7 .

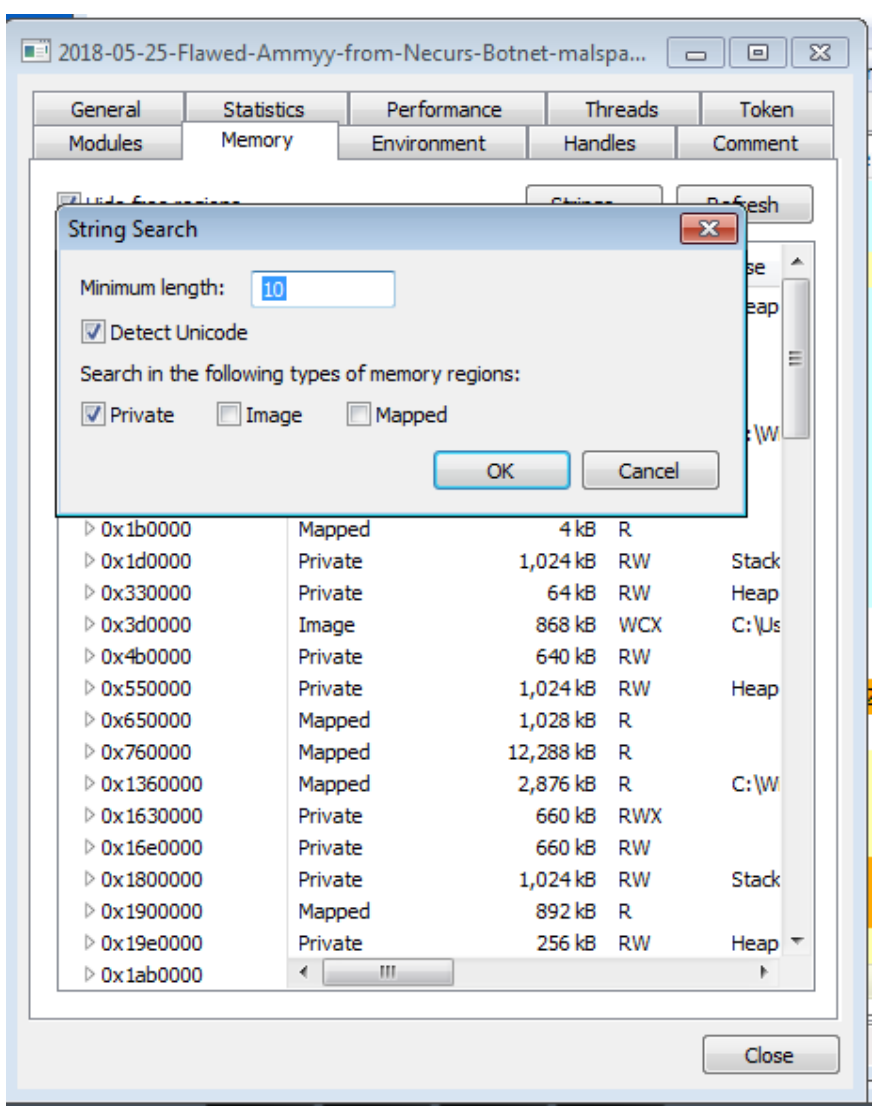

Gbr 7 tampilan string search pada fitur process hacker

Merujuk Gbr 7 untuk mencari proses yang berupa string atau kata yang terdapat pada file Little.dll yang telah berjalan menggunakan process hacker dapat ditemukan pada properties -> memory -> string.

Hasil data informasi yang didapat dari malware teserbut cukup banyak, berikut sebagian informasi aktivitas malware yang terdapat pada sampel malware Flawed Ammyy RAT yang diteliti diunjukkan pada tabel III sebagai berikut: 


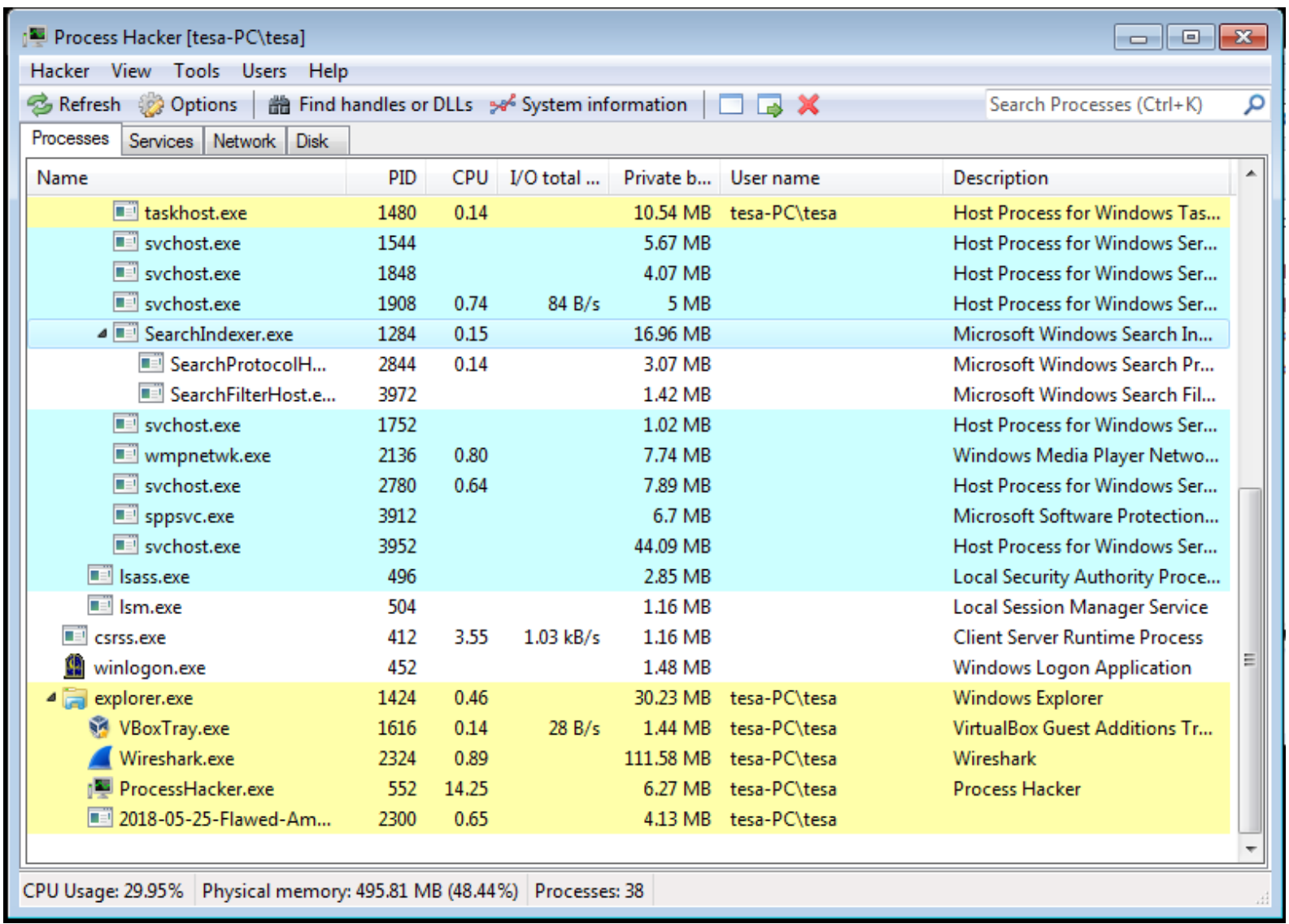

Gbr. 6 Tampilan process hacker setelah runnig malware

Tabel III merupakan hasil string malware Flawed Ammyy menggunakan tool proses hacker. String tersebut menunjukkan bagaimana malware flawed ammyy berjalan pada system.

4) Gathering first snapshot of the registry

Tools yang digunakan untuk melakukan gathering a first snapshot of the registry menggunakan Regshot versi 1.9.0. Regshot, monitoring perubahan pada registry menggunakan aplikasi regshot. Hasil keluaran dari Regshot menunjukkan berapa jumlah perubahan registri dan apa serta di mana saja perubahan tersebut ditunjukkan pada Gbr 8 .

Hasil dari shot registry pertama sebelum malware dijalankan dengan shot registry setelah malware dijalanakan terlihat ada beberapa perubahan registry pada sistem operasi setelah malware di jalankan, total perubahan adalah 50 perubahan, dimana 2 penghapusan keys, 5 penambahan keys, 4 penghapusan values, 9 penambahan values dan 30 perubahan values pada registry.

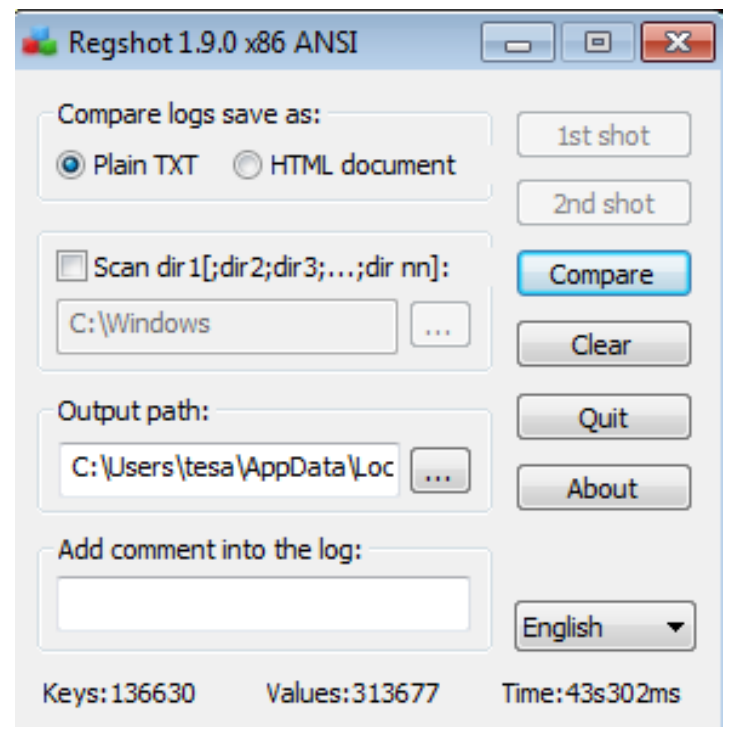

Gbr. 8 Tampilan Regshot 
TABEL III

STRING MALWARE FLAWED AMMYY RAT

\begin{tabular}{|c|c|c|}
\hline No. & $\begin{array}{c}\text { Address dan Result } \\
\end{array}$ & Keterangan \\
\hline 1 & $\begin{array}{l}\text { Ox2flb6b! This program cannot be run in } \\
\text { DOS mode. }\end{array}$ & Malware tidak dapat berjalan ketika mode DOS \\
\hline 2 & $0 \times 2 f 2 e c 2$ kernel32.dll & Windows NT BASE API Client DLL \\
\hline 3 & $0 x 2 f 2 f 2 b$ LoadLibraryA & $\begin{array}{l}\text { Malware memuat modul yang ditentukan ke dalam ruang } \\
\text { alamat dari proses panggilan }\end{array}$ \\
\hline 4 & Ox2f2f38 GetProcAddress & $\begin{array}{l}\text { Malware mengambil alamat fungsi atau variabel yang diekspor } \\
\text { dari pustaka dynamic-link yang ditentukan }\end{array}$ \\
\hline 5 & Ox2f2f47 VirtualAlloc & $\begin{array}{l}\text { Malware mengubah keadaan suatu wilayah halaman di ruang } \\
\text { alamat virtual dari proses panggilan }\end{array}$ \\
\hline 6 & Ox2f2f54 VirtualProtect & $\begin{array}{l}\text { Malware mengubah perlindungan akses proses apa pun pada } \\
\text { lingkungan virtual }\end{array}$ \\
\hline 7 & Ox2f2f98 FreeConsole & Malware melepaskan proses panggilan dari konsolnya \\
\hline 8 & $\begin{array}{l}\text { Ox3b0f93 } \\
\text { ComSpec }=C: \backslash \text { Windows } \backslash \text { system } 32 \backslash \mathrm{cmd} . \text { exe }\end{array}$ & Malware membaca spesifikasi komputer korban \\
\hline 9 & Ox3bOfb7 FP_NO_HOST_CHECK=NO & Malware melakukan cek apakah ada host atau tidak \\
\hline 10 & $\begin{array}{l}\text { Ox3e6660 Security=Impersonation Dynamic } \\
\text { True }\end{array}$ & Malware menjalakan peniruan pada security \\
\hline 11 & Ox3e8194 Ammyy Admin & Menjalakan perintah dasar ammyy admin \\
\hline 12 & $0 x 3 e d c 50103.208 .86 .69$ & Ip address tujuan \\
\hline 13 & Ox3felfo NT AuthorityWetworkService & $\begin{array}{l}\text { Malware melakukan pengaturan akses keamanan untuk folder } \\
\text { bersama pada jaringan }\end{array}$ \\
\hline 14 & $0 \times 3 f e 7 a 4$ root $\mathrm{Security}$ Center 2 & $\begin{array}{l}\text { Malware masuk ke root kemudian melakukan akses ke security } \\
\text { center } 2\end{array}$ \\
\hline 15 & Ox4098d4 Remote Desktop Services & Malware mejalankan service remote desktop \\
\hline 16 & $\begin{array}{l}\text { Ox40a2f6 } \\
\text { windows_tracing_logfile }=C: \backslash B V T B i n \backslash T e s t s \backslash i n \\
\text { stallpackage } \backslash \text { csilogfile.log }\end{array}$ & Malware mencoba membaca $\log$ pada komputer yang terinfeksi \\
\hline 17 & $\begin{array}{l}\text { Ox40efed } \quad \text { id }=52399915 \& \text { os }=7 \\
x 86 \& \text { priv }=\text { User }+ \text { UAC\&cred }=\text { tesa- } \\
\text { PC\tesa\&pcname }=\text { TESA- } \\
\text { PC\&avname }=\& \text { \&uild_time }=25-12-\end{array}$ & $\begin{array}{l}\text { Malware menyimpan data yang ada pada komuter yang } \\
\text { terinfeksi, seperti operasi sistem, user, dan pc name }\end{array}$ \\
\hline 18 & $\begin{array}{l}\text { Ox482c94 ERROR: Couldn't connect to router } \\
\text { 103.208.86.69:443 }\end{array}$ & $\begin{array}{l}\text { Malware tidak dapat koneksi pada router tujuan karena ketika } \\
\text { proses analisis jaringan pada komputer telah dilakukan virtual } \\
\text { network }\end{array}$ \\
\hline
\end{tabular}

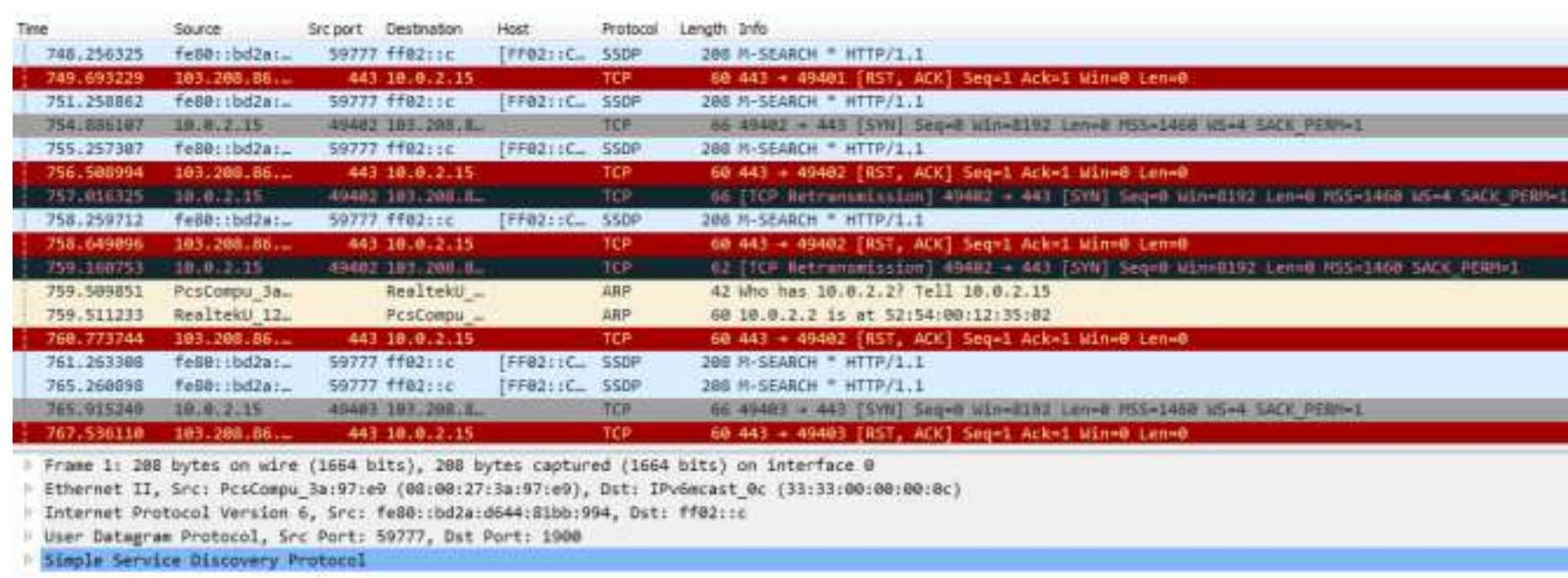

Gbr. 9 Hasil capture WireShark terhadap paket data malware 
5) Setting up network trafik

WireShark, sebagai alat software monitoring dan juga analisis jaringan, menangkap paket secara real time dan menampilkannya dalam format yang dapat dibaca. Aplikasi ini digunkan dalam penelitian untuk mengetahui aktivitas malware terhadap jaringan.

Merujuk dari gambar 9 hasil capture WireShark dapat dilihat bahwa pc atau komputer virtual mesin yang terinfeksi malware Flawed Ammyy RAT dengan ip address 10.0.2.15 selalu melakukan singkron terhadap ip address 103.208.86.69 yang telah di jelaskan sebelumnya pada tahap starting process explore dimana ip address ini merupakan ip address router attacker. Dilihat pada gambar 4.10 virtual mesin hanya bisa melakukan sinkron terhadap attacker ini karena jaringan yang telah dilakukan virtual network, malware tidak dapat melakukan komunikasi atara malware dengan router attacker.

\section{B. Reverse engineering}

Proses disassembler ini menggunakan tools IDAPro Setelah malware terbuka selanjutnya adalah melakukan analisa command yang ada didalam malware. Berikut ini adalah gambar hasil disassembler malware menggunakan tools IDAPro ditunjukkan pada Gbr.10.

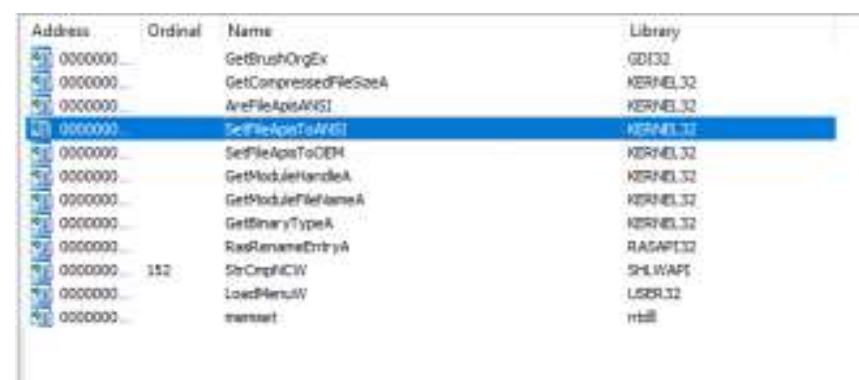

Gbr. 10 Disassembler malware Flawed Ammyy RAT

Pada Gbr.10 menunjukkan malware flawed ammyy RAT menggunakan 12 function untuk melakukan infeksi dan melakukan penyerangan pada system yang telah terinfeksi malware flawed ammyy rat. 12 function tersebut dijelaskan pada Tabel IV.

TABEL IV

HASIL DISSEMBLER

\begin{tabular}{|c|c|}
\hline Hasil dissembler & Keterangan \\
\hline $\begin{array}{l}\text { BOOL_stdcall Get GetBrushOrgEX(HDC hdc, } \\
\text { LPPOINT lppt) } \\
\text { extrn GetBrushOrgEX:dword }\end{array}$ & $\begin{array}{l}\text { Malware memamnggil function tersebut untuk mengambil alih fungsi } \\
\text { pointer agar dapat mempermudah pencurian data. }\end{array}$ \\
\hline $\begin{array}{l}\text { DWORD_stdcall GetCompressedFileSizeA (LPCSTR } \\
\text { lpFileName, LPDWORD lpFileSizeHigh) } \\
\text { extrn GetCompressedFileSizeA:dword }\end{array}$ & $\begin{array}{l}\text { Malware memanggil function diatas untuk melakukan proceses } \\
\text { compress file tertentu kemudian menyimpannya. }\end{array}$ \\
\hline $\begin{array}{l}\text { BOOL_stdcall AreFileApisAnsi() } \\
\text { extrn AreFileApisAnsi:dword }\end{array}$ & $\begin{array}{l}\text { Perintah dengan function tersebut malware dapat menentukan apakah } \\
\text { fungsi file I / O menggunakan halaman kode karakter ANSI atau } \\
\text { OEM. }\end{array}$ \\
\hline $\begin{array}{l}\text { Void_stdcall SetFileApisToAnsi() } \\
\text { extrn SetFileApisToAnsi:dword }\end{array}$ & $\begin{array}{l}\text { Function tersebut malware dapat membuat file I / O berfungsi untuk } \\
\text { menggunakan halaman kode set karakter ANSI untuk proses saat ini. } \\
\text { Fungsi ini berguna untuk operasi input dan output masukan 8-bit. }\end{array}$ \\
\hline $\begin{array}{l}\text { Void_stdcall SetFileApisToOEM() } \\
\text { extrn SetFileApisToOEM:dword }\end{array}$ & $\begin{array}{l}\text { Function tersebut dapat membuat file I / O berfungsi untuk proses } \\
\text { untuk menggunakan halaman kode karakter set OEM. Fungsi ini } \\
\text { berguna untuk operasi input dan output masukan 8-bit. }\end{array}$ \\
\hline $\begin{array}{l}\text { HMDULE_stdcall GetModuleHandleA(LPCSTR } \\
\text { lpModuleName) } \\
\text { extrn GetModuleHandleA:dword }\end{array}$ & $\begin{array}{l}\text { Malware dengan function tersebut memilih file yang memenuhi } \\
\text { syarat yang mengandung modul tertentu. }\end{array}$ \\
\hline $\begin{array}{l}\text { DOWRD_stdcall GetModuleFileNameA(HMODULE } \\
\text { hModule, LPSTR lpFilename, DOWRD nSize) } \\
\text { extrn GetModuleFileNameA:dword }\end{array}$ & $\begin{array}{l}\text { Malware dengan function tersebut dapat meneangani modul yang } \\
\text { telah ditentukan }\end{array}$ \\
\hline $\begin{array}{l}\text { BOOL_stdcall GetBinaryTypeA(LPCSTR } \\
\text { lpApplictionName, LPDWORD lpBinaryType }) \\
\text { extrn GetBinaryTypeA:dword }\end{array}$ & $\begin{array}{l}\text { Function tersebut malware dapat menentukan apakah file dapat di } \\
\text { eksekusi, jika ia subsistem mana yang menjalankan file yang dapat } \\
\text { dieksekusi }\end{array}$ \\
\hline $\begin{array}{l}\text { DWORD_stdcall RasRenameEntryA(LPCSTR, } \\
\text { LPCSTR LPCSTR) } \\
\text { extrn RasRenameEntryA:dword }\end{array}$ & $\begin{array}{l}\text { Malware dengan function RasRenameEntry dapat mengubah nama } \\
\text { entri di buku telepon. }\end{array}$ \\
\hline extrn StrCmpNCW:dword & $\begin{array}{l}\text { Mmalware dapat membandingkan nomor spesifik sejumlah karakter } \\
\text { dari awal dua string menggunakan C run-time (ASCII) }\end{array}$ \\
\hline $\begin{array}{l}\text { HMENU_stdcall LoadMenuW(HINSTANCE } \\
\text { hInstance, LPCWSTR lp MenuName) } \\
\text { extrn RasRenameEntryA:dword }\end{array}$ & $\begin{array}{l}\text { Malware dapat memuat sumber daya menu yang spesifik dari file } \\
\text { yang dapat executable (.exe) yang terkait dengan instance aplikasi. }\end{array}$ \\
\hline $\begin{array}{l}\text { void_cdecl memset(void } * D s t, \text { int Val, size_t Size) } \\
\text { extrn_imp_memset:dword }\end{array}$ & Malware melakukan setel buffer ke karakter yang ditentukan \\
\hline
\end{tabular}




\section{Malware workflow}

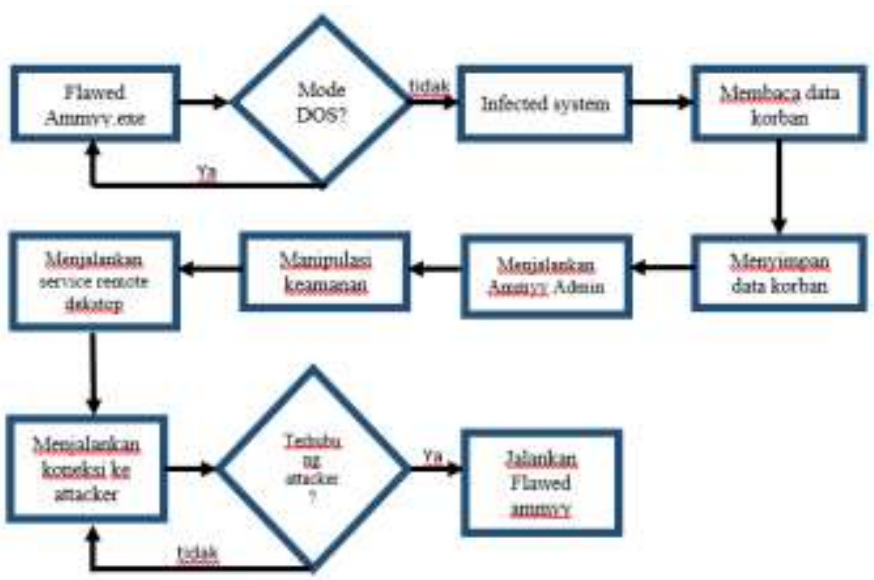

Gbr. 11 proses dari malware Flawed Ammyy RAT

Merujuk pada Gbr 11 cara kerja malware Flawed Ammyy $R A T$ sebagai berikut:

1) Malware yang telah dijalankan akan melakukan infected pada sistem. Malware akan membaca data yang ada pada komputer korban, seperti operasi sistem yang digunakan, username, dan PC name, kemudian malware akan menyimpan data tersebut.

2) Malware akan menjalankan perintah dasar ammy admin selain sebagai remote access, menjalakan ammyy adminini bertujuan untuk memanipulasi keamana seolah-olah ammyy admin yang berjalan pada sistem.

3) Malware selanjutnya akan melakukan koneksi dengan server attacker. Malware akan melakukan sinkron dengan server terlebih dahulu, setelah sinkron server akan merespon. Malware akan mengirimkan data spesifikasi yang dimiliki komputer korban, seperti operasi system, user dan pc name.

\section{Pencegahan malware}

1) Proses pencegahan untuk melindungi mail server dari serangan malware agar mail server tidak terinfeksi malware dan malware tidak akan melakukan broadcast malware spam pada sistem, bagi para administrator server dapat melakukan hal-hal berikut ini:

- Admin lakukan update firewall versi terbaru

- Admin menggunakan Antispam pada mail server, contoh tools antispam seperti zero bounce, spam titan, barracuda spam firewall, dan lain-lain

- Admin lakukan konfigurasi mail relay, hindari relay terbuka bagi pengirim spam dengan menentukan domain atau alamat ip mana yang akan digunakan oleh mail server

- $\quad$ Admin lakukan Encryption pada encrypt POP3, IMAP authentication, gunakan SSL dan TLS

- Admin lakukan Koneksi dan default setting untuk menghindari serangan $D O S$, batasi jumlah koneksi dan kesalahan otentikasi yang akan diterima oleh system, hapus fungsi server tidak dibutuhkan dengan melakukan nonaktif pada pengaturan default yang tidak diperlu.

- System miliki mail server khusus dan memindahkan layanan lain seperti FTP ke server lain,

- Admin lakukan control access untuk melindungi mail server, terapkan authentication seperti authentication SMTP pengguna harus memberi username dan password untuk dapat melakukan pengiriman melalui server

- Admin lakukan periksa daftar DNS-based blacklists (DNSBL) dan tolak email dari domain atau IP apapun yang terdaftar didalamnya

- Admin lakukan periksa URL Real-Time blocklists dan tolak pesan berisi tautan tidak valid atau berbahaya

- Admin lakukan maintain blacklists dan block IP yang secara khusus menyerang mail server Pemulihan system setelah terinfeksi malware

2) Proses pencegahan untuk melindungi pengguna dari serangan malware agar data pengguna aman dari serangan malware khususnya malware Flawed Ammyy RAT, bagi para pengguna dapat melakukan hal-hal berikut:

- Pengguna tidak membuka email dari pengirim yang tidak dikenal

- Pengguna tidak mudah percaya apabila tiba-tiba menerima email dari pengirim yang dikenal

- Pengguna tidak melakukan unduhan file yang mencurigakan dan dari sumber yang mencurigakan

- Pengguna tidak melakukan klik link phising. Domain yang mirip sering digunakan hacker untuk menjebak user yang kurang berhati hati, kurang cermat. Phishing yang paling sering ditemui biasanya adalah phising pada akun media sosial, situs palsu tersebut tersebar dengan menggunakan foto-foto porno, memancing korban untuk melakukan kilk, tidak jarang foto tersebut menyerupai sebuah video yang siap di klik. maka dari itu sebaiknya cermati lagi alamat tujuannya.

- Pengguna melakukan install antivirus dan aktifkan antivirus

- Pengguna lakukan pindai komputer secara berkala

E. Ciri-ciri komputer terinfeksi malware Flawed Ammyy RAT

Berikut ini ciri-ciri system terinfeksi malware Flawed Ammyy RAT:

- Sistem pada task manager ada proses yang tidak dikenal

- Sistem pada wifi status atau local area network status aktifitas sent lebih besar disbanding download

- Kursor pada sistem bergerak sendiri

F. Pemulihan system setelah terinfeksi malware

Korban yang telah terinfeksi malware Flawed Ammyy $R A T$ dapat melakukan hal-hal berikut ini

- Pengguna melakukan putus koneksi dengan jaringan apapun, baik itu $L A N$ maupun access point.

- Pengguna yang menggunakan windows 10 buka task manager kemudian lihat pada bagian details klik Flawed Ammyy RAT kemudian end task 
- Pengguna yang menggunakan windows 7 buka task manager kemudian lihat pada process klik Flawed Ammyy RAT kemudian klik end process

- $\quad$ Sistem setelah malware tidak berjalan, lakukan install antivirus dan pemindaian.

- Pengguna lakukan ganti user name komputer

- Sistem yang sebelumnya user tidak di password, sekarang lakukan password pada user

- Sistem yang sebelumnya user menggunakan password, ganti password yang dulu sebelum terinfeksi malware

- Pengguna lakukan ganti user name password social media yang diakses melalui komputer yang terinfeksi

- Pengguna yang melakukan internet banking, segera ganti pin atau username password akun internet banking.

\section{KESIMPULAN}

Berdasarkan hasil yang diperoleh dari pembahasan dan hasil penelitian ditarik kesimpulan, proses identifikasi malware dapat dengan dua metode yaknik analisis dinamis dan reverse engineering menggunakan proses disassembler. Proses analisis dinamis dimulai dari instalasi virtual mesin, setting up virtual network, starting process explorer, gathering a first snapshot of the registry, setting up network trafik. Hasil dari proses identifikasi malware Flawed Ammyy RAT menggunakan metode dinamis dan reverse engineering telah dilakukan dokumentasi berupa jurnal ilmiah.

Cara kerja malware Flawed Ammy RAT ini tidak dapat berjalan ketika korban sedang keadaan mode DOS. Malware melakukan infeksi pada system, membaca dan menyimpan data yang ada pada komputer. Mejalankan Ammy Admin dan memanipulasi keamanan, melakukan aktif remote desktop. Koneksi dengan attacker pada ip address 103.208.86.69 dan melakukan pengiriman data yang ada pada komputer, ketika korban dan attacker sinkron, attacker dapat dengan mudah remote access jarak jauh tanpa sepengetahuan korban. Malware menggunakan 12 function untuk melakukan infeksi dan penyerangan pada system.

Kelebihan dari penelitian ini dapat menjelaskan alur analisis dinamis dengan rinci, kemudian menambakan satu tahapan yakni virtual network pada virtual mesin yang digunakan sebagai lab analisis malware. Reverse engineering dengan teknik disassembler dapat mempermudah proses investigasi mendalam mengenai pergerakan malware. Kekurangan dari penelitian ini adalah tidak dapat melihat lebih jauh penyerangan yang malware lakukan pada system, karena malware yang telah melakukan infeksi pada system tegantung pada perintah attacker selanjutnya, untuk melakukan tahap tersebut system yang terinfeksi malware Flawed Ammyy RAT harus melakukan koneksi dengan attackernya kemudian attacker akan menjalakan fitur lain yang ada pada malware Flawed Ammyy RAT.

\section{UCAPAN TERIMA KASIH}

Penulis mengucapkan bersyukur kepada Allah swt, karena berkat rahmat dan barokahnya penulis dapat menyelesaikan penelitian ini. Penulis mengucapkan terimakasih kepada para pembimbing yang sabar mengajarkan dan mmbimbing penulis, kepada orang tua atas segala dukungan dalam bentuk apapun serta pihak-pihak yang terkait yang telah membantu penulis dalam menyelesaikan penelitian ini.

\section{DAFTAR PUSTAKA}

[1] N. Zalavadiya and S. Priyanka, "A Methodology of Malware Analysis, Tools and Technique for Windows Platform - RAT Analysus," 2017.

[2] S. C. Y. Hutauruk, F. A. Yulianto and G. B. Satrya, "Malware Analysis Pada Windows Operating System Untuk Mendeteksi Trojan," $e$ Proceding of Enggineering , vol. III, no. 2, pp. 3590-3595, 2016.

[3] R. Adenansi and L. A. Novarina, "Malware Dynamic," JOEICT (Jurnal of Education and Information Communication Technology), vol. 1, no. 1, p. 37, 2017.

[4] D. R. Septani, N. Widiyasono and H. Mubarok, "Investigasi Serangan Malware Njrat Pada PC," Jurnal Edukasi dan Penelitian Informatika (JEPIN), vol. II, no. 2, pp. 123-128, 2016.

[5] T. A. Cahyanto, V. Wahanggara and D. Ramadana, "Analisis dan Deteksi Malware Menggunakan Metode Analisis Dinamis," JUSTINDO, Jurnal Sistem \& Teknologi Informasi Indonesia, vol. II, no. 1, pp. 19-30, 2017.

[6] U. K. Bavishi and B. M. Jain, "Malware Analysis," International Journals of Advanced Research in Computer Science and Software Engineering, vol. VII, no. 12, pp. 27-33, 2017.

[7] D. Uppal , V. Mehra and V. Verma, "Basic on Malware Analysis, Tools, and Technique," International Journal on Computational Sciences \& Applications (IJCSA) Vol.4, No.1, pp. 103-112, 2014.

[8] A. H. Muhammad, B. Sugiantoro and A. Luthfi, "Metode Klasifikasi dan Analisis Karakteristik Malware Menggunakan Konsep Ontologi," Tenomatika, vol. IX, no. 2, pp. 16-28, 2017.

[9] H. A. Nugroho and Y. Prayudi, "Penggunaan Teknik Reverse Engineering Pada Malware Analysis Untuk Identifikasi Serangan Malware," KNSI 2014, 27-28 Februari 2015, STMIK Dipanegara Makasar, pp. 1-8, 2015.

[10] Proofpoint Staff, "Proofpoint," 7 Maret 2018. [Online]. Available: https://www.proofpoint.com/us/threat-insight/post/leaked-source-codeammyy-admin-turned-flawedammyy-rat.

[11] K. Sheridan, "Darkreading," 12 Maret 2018. [Online]. Available: https://www.darkreading.com/endpoint/flawedammyy-rat-campaignputs-new-spin-on-old-threat/d/d-id/1331248.

[12] A. Saraswat, "Hacking, Hacking Tools, Vulnerability," 10 Maret 2018. [Online]. Available: https://professionalhackers.in/beware-offlawedammyy-rat-that-steals-credentials-and-record-audio-chat/.

[13] S. Y. S, Y. Prayudi and I. Riadi, "Implementation of Malware Analysis using Static and Dynamic Analysis Method," International Journal of Computer Applications, vol. CXVII, no. 6, pp. 11-15, 2015.

[14] K. Ki-Su, S. Hyo-Jeong and K. Hyong-Shik, "A Bit Vector Based Binary Code Comparison Method for Static Malware Analysis," Journal of Computers, vol. xiii, no. 5, pp. 545-554, 2018.

[15] A. Zimba, L. Simukonda and M. Chishimba, "Demystifying Ransomware Attacks: Reverse Engineering and Dynamic Malware Analysis of WannaCry for Network and Information Security," ZAMBIA INFORMATION COMMUNICATION TECHNOLOGY (ICT) JOURNAL, vol. i, no. 1, pp. 35-40, 2017.

[16] B. Thakar and C. Parekh, "Reverse Engineering of Bonet (APT)," Information and Communication Technology for Intelligent Systems, vol. ii, no. 1, pp. 252-262, 2017. 